19 日のように痕跡程鹿に急減することがあるが，一方 $\mathrm{Cl}^{-}, \mathrm{Br}^{-}$は比校的規則正しい变化を示している。

3） 1952 年 1 月末および 1954 年 3 月 8 日より同年 5 月 22 日の間の 2 回の主成分の不連続逆転》の際に を $\mathrm{Br}^{-}, \mathrm{I}^{-}$は $\mathrm{Cl}^{-}$と正の関保を維持し特別な变化就め られない。

4） $\mathrm{Br}-/ 1$ - 重量比をとると 1952 年 4 月〜 9 月の活 動期の值に较べ，同年 10 月以降の静稳期がー段に大き い値をとっているととがかかる。そこで，その变化の原 因が $\mathrm{Br}^{-}, \mathrm{I}^{-}$のいずれの側にあるかを知るために第7 荠を求めた。

\begin{tabular}{|c|c|c|c|}
\hline & $\frac{\mathrm{Cl}^{-}}{(\mathrm{g} / \mathrm{l})}$ & $\underset{(\mathrm{mg} / l)}{\mathrm{Br}^{-}}$ & $\underset{(\mathrm{mg} / l)}{\mathrm{I}-}$ \\
\hline 活動期 (1952 年) & 4.18 & 6.2 & 2.7 \\
\hline 静棇期 (1954 年) & 3.11 & 4.9 & 1.8 \\
\hline $\begin{array}{l}\text { 饻化率 }=\frac{\text { 活動期 }}{\text { 静稳期 }} \\
\text { 対端素烄化率比 }\end{array}$ & 1.3 & $\begin{array}{c}1.2 \\
\frac{1.2}{1.3}=0.9_{2}\end{array}$ & $\begin{array}{c}1.5 \\
\frac{1.5}{1.3}=1.15\end{array}$ \\
\hline
\end{tabular}

すなわち $\mathrm{Cl}^{-}, \mathrm{Br}^{-}, \mathrm{I}^{-}$の变化率を, 1952 年の活動 期で一底, $\mathrm{Cl}^{-}, \mathrm{Br}^{-}, \mathrm{I}^{-} の$ constancy の維推されて
いる4 月 16 日，4月 22 日， 5 月 17 日の平均值と， 静樘期の. 1954. 年 6 月 28 日， 8 月 13 日，9月 8 日の 平均值によって比乾した。定量的な取拔い193は別として 定性的には变化率は $\mathrm{I}^{-}, \mathrm{Cl}^{-}, \mathrm{Br}^{-}$の順になると考え られる。したがって第6 表の $\mathrm{Br}^{-} / \mathrm{I}^{-}$の变化は $\mathrm{Br}^{-}$よ りは I- の変動によるものであるととがわかる。とくに 自然界の他资料荟へ濃縮率の高い I- が最大の变化率 を示し濃縮率の低い $\mathrm{Br}^{-}$が最も安定であることは興味 梁いととで，岩漿分化の最終段階であるこの期において

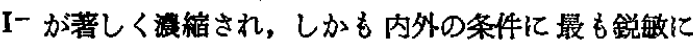
反応しているととを示すものであろう。

とにかく，以上の結果は，定量的な取扱いは別とし $\tau$, この3元素の間に hydrothermal differentiation の存在するととを示するのと考光られる。

最後に御指導と衔搝助をいただいた北海道大学病院登

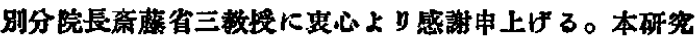
は交部省科学研究費により行われ， $\mathrm{Br}^{-}$の定量は那須 莪和氏の手をわづらわした，併せて感謝の意を表する。 （明和 30 年 4 月，日本化学会第 8 年会講演）

19) H. Neumann, Econ. Geol. 43, 77 (1948); 本報飞おいて 6 end-magmatic $\xi$ exo-magmatic hydrothermal differentiation 併若える。

\title{
鉄銅中ケイ素の比色定法について
}

成田貫 一

I. 緒

Diénert, Wandenbulcke1) の研究が発表されて以 来, ケイ素の比色定量は黄色のケイモリブデン酸の生成 を利用して行われている。たとえば, Swank, Mellon, Schwartz 弓 2) 4) 仗天然水中のケ 酸の定量保, Pinsl,

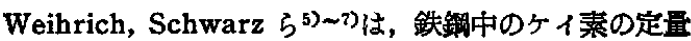

1) F. Diénert, F. Wandenbulcke, Compt. rend. 176, 1478 (1923).

2) H. W. Swank, M. G. Mellon, Ind. Eng. Chem. Anal. Ed. 6, 348 (1934).

3) M. C. Schwartz, Ind. Eng. Chem. Anal. Ed. 6, 364 (1934).

4) H. W. Kundson, C. Juday, Y. M. Meloche, Ind. Eng. Chem. Anal. Ed. 12, 270 (1940).
にそれぞれとのケィモリブデン酸比色法を用いている。 著者名を従来よりての方法およびモリブデン青法を用い ているが，正確な值の得られない場合がある。てれは鉄 銅中に存在しているケイ素の形，武料溶液中のケイ酸の 形態ならびに比色条件によるものと考えられる。

溶液中のケイ酸には，弱酸性下でモリブデン酸イオン と反広して黄色のケイモリブデン酸を生ずる と,そうでない $\beta$-ケ洒夋のあるとと，ならびに両ヶィ 酸の分析化学的意義, 相互の量的関係についてはすでに

5) H. Pinsl, Arch. Eisenhuttenwes. 10, 139 (1936/1937).

6) R. Weihrich, W. Schwarz, Arch. Eisenhattenwes. 14, 501 (1940/1941).

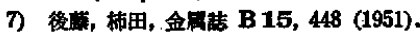

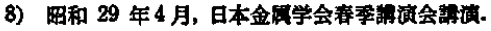


述べたす。っそてで本報においては，定量法に関する二， 三の娭傠結果を述べる。

\section{II. 標準ケイ亲溶液および装置}

標準溶液は精製無水ケイ酸をケイ酸塩分析用炭酸ナト リウムと共に白金ルツボ中で溶飾し，椧却後てれを蒸留 水にとかして一定嶩度のケイ酸ナトリウム溶液を調製し た9)。濃度はあらかじめ重量法により決定し，必要に店 ビて適当な湌度に希釈して用いた。本溶液の保存にはポ リエチレン瓶を使用した。その他試薬はすべて市販特級 品を使用した。溶液の吸光係数の測定には Beckmann, DU 望分光光電光度計を, $\mathrm{pH}$ の測定には島津製作所筫 GU-1 型 pH 計（ガラス電極）を用いた。実験はす心゙ て室温 $\left(26 \pm 1^{\circ} \mathrm{C}\right)$ の下で行った。

\section{III. ケイモリブテン酸反応}

\section{（1）ケイモリブデン酸溶液の吸収スペクトル}

比色分析における黄色ケィモりブデン酸溶液の四光保 数測定波長は，第 1 表に示したように，各実駼者によっ てかなり相違している。1951年 Armand, Berthaux ${ }^{13)}$ の測定した鱂収スペクトルによれば，500－305 m $\mu$ の波 長範囲では，波長が短かくなるにつれて吸光保数は連 綕的に增大している。著者は $50 \mathrm{~m} l$ 中にヶ 傃 0.30 お 上び $0.50 \mathrm{mg}, 10 \%$ モリブデン酸アンモニウム溶液各

\section{第 1 表 财光保数の湘定波長}

$370 \mathrm{~m} \mu:$ J. Hure, T. Ortis ${ }^{10)}$

$380 \mathrm{~m} \mu$ : 成田 ${ }^{9}$

$390 \mathrm{~m} \mu$ : R. Guenther, R. H. Gale ${ }^{11)}$

$390 \sim 400 \mathrm{~m} \mu$ : U. T. Hill12)

$400 \mathrm{~m} \mu$ : M. Armand, J. Berthaux ${ }^{13)}$

$405 \mathrm{~m} \mu$ : J. R. Boyd $\mathrm{d}^{14)}$

$410 \mathrm{~m} \mu$ ： O. P. Case ${ }^{15}$, 珹田 ${ }^{2)}$

$420 \mathrm{~m} \mu$ : D. Rozental, H. C. Campbell ${ }^{16)}$

$425 \mathrm{~m} \mu$ : G. N. Cade ${ }^{17)}$

$436 \mathrm{~m} \mu:$ H. Pins $1^{5)}$, 後藤, 柿田》)

9) 成田, 本詰 76, 460 (1955),

10) J. Hure, T. Ortis, Bull. Soc. Chim. France 1949,834.

11) R. Guenther, R. H. Gale, Anal. Chem. 22, 1510 (1950).

12) U. T. Hill, Anal. Chem. 21, 589 (1949).

13) M. Armand, J. Berthaux, Anal. Chim. Acta 5, 380 (1951).

14) J. R. Boyd, Anal. Chem. 24, 805 (1952).

15) O. P. Case, Ind. Eng. Chem. Anal. Ed. 16, 309 (1944).

16) D. Rozental, H. C. Campbell, Ind. Eng. Chem. Anal. Ed. 17, 222 (1945).

17) G. N. Cade, Ind. Eng. Chem. Anal. Ed. 17, 372 (1945),
$2 \mathrm{ml}$ を含む $\mathrm{pH} 1.3$ の溶液の吸収スペクトルを測定し た。ブランクにはケイ素を含まない同様の溶液を用い た。その結果は第 1 図のとおりであって，なるべく短か い波長を用いると都合よいように考えられるが，波長が 短かくなるにしたがって，実際の分析操作では微量の共 存イオンによるブランク值が大きくなるてと，ならびに 測定の签易さ等を考虑すると $410 \mathrm{~m} \mu$ の笚色光が適当 である。

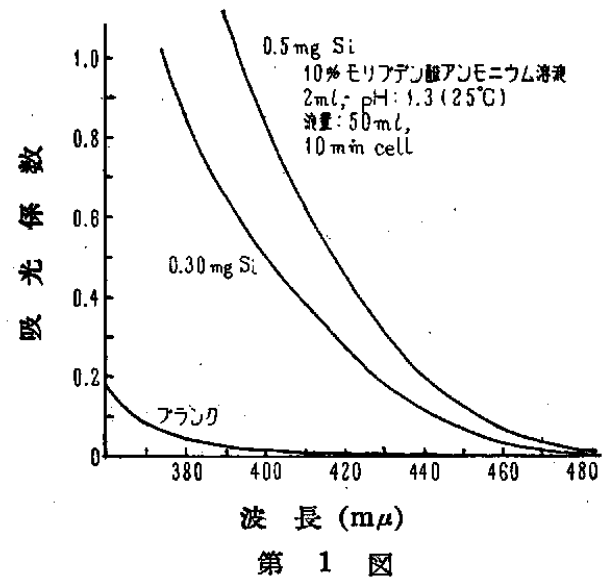

(2) ケイモリブデン酸生成におよぼす pH の影

ケイ素溶液一定量を $150 \mathrm{~m} l$ フラスコにとり，てれに 3N 碳酸の添加量を種々变えて加光，酸性度を異にする 溶波各 $45 \mathrm{ml}$ を調製した。つぎに各々に $10 \%$ モりブデ ン酸アンモ二ウム溶液 $2 \mathrm{~m} l$ を加光，湯煎上で $50^{\circ} \mathrm{C}$ に 5 分間加温した後冾却し，全容積を $50 \mathrm{~m} l$ に希釈し，巾 $10 \mathrm{~mm}$ の液槽を用いて波長 $410 \mathrm{~m} \mu$ の下で溶液の吸光 係数を測定した。その結果恃第2四のとおりであって， pH が高い時はケイモリブデン酸の生成は不完全で発色 摔は低いが， $\mathrm{pH}$ の減少と共に発色率は增大し， $\mathrm{pH} 1.6$ で 100\% に達する。そして pH 1.6〜1.0 の籍囲では 晤光保数は一定である。とてろがさらに $\mathrm{pH}$ が減少して 強酸性になるとケイモリブデン酸は不安定となり吸光係 数は減少する*。此上の実騟結果からケイモりブデン酸

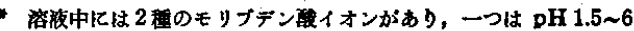
の筈围て安定な 6，7-ポリ・モリブデン酸イオンて，他の一つは $\mathrm{pH}$ 1.0 1.5 の範国で安定な 12-ポリ・モりブデン酸イオンであ

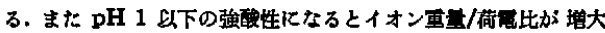
しイオンのポテンシェルが低下するため重合しやすくなる。 また G. Carpeni, Bull. Soc. Chim. France 14, 496 (1947)

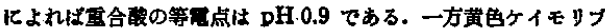
デン酸はケイ秦を中心原子とする 12-ポリ・モリブデン酸鉷埴

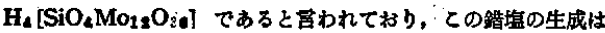
本交に速べたように pH 1.0 1.6 の籍囲で完全である. てのよ ラにモリブデン㲀イオンと黄色ケイモリブデン酸イオンの安定に

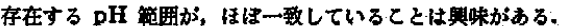




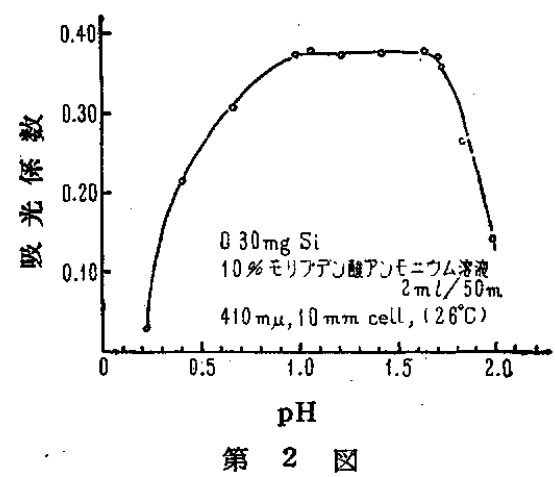

生成の最適水熬イオン浱度は $\mathrm{pH}$ 1.6〜1.0 の範囲であ りしたがって比色はての範围で行わねばならない。

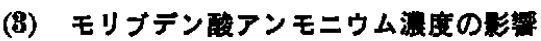

ケイ素溶液一定量をとり，はぼ中和した後 3N 硫酸 $1.5 \mathrm{~m} l$ を加え液量を $45 \mathrm{~m} l$ 亿し，モリブデン酸アンモ ニウム溶液*を種々量加え, 前記 (2) の要領で発色させ て吸光係数を測定した。その実験結果を第 3 四に示し た。溶液中のケイ菜量にもよるが，10\%モリブデン酸 試薬 $0.5 \mathrm{~m} l$ の場合は，ケイモリブデン酸の生成は不完 全である。1 $6 \mathrm{~m} l$ では最大発色率を示し，ケイモリブ デン酸の生成は完全に行われる。しかし添加量が $7 \mathrm{ml}$ 以上になると，かえって吸取俰数の隇少か認められる。 以上の笑験結果ならびにケイ素の定量範囲を考潈して， 発色に十分な最少量として 10\% モリブデン酸アンモニ ウム溶液 $2 \mathrm{~m} l$ を加えるととにした。

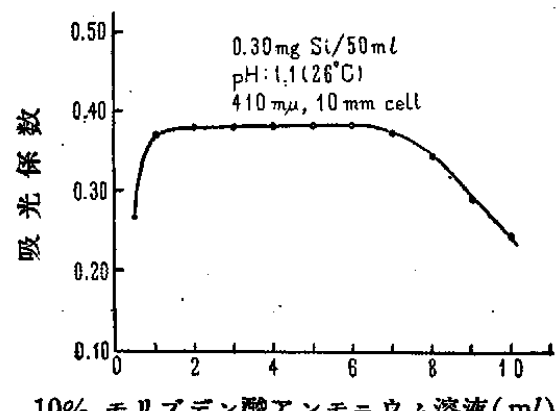

第 3 因

(4) ケイモリブデン酸生成速度におよぼす泪农の影

生成速度におよばす温度の影鄉を調べるため，ケイ革 溶液をはほ中和した後 $3 \mathrm{~N}$ 硫酸 $1.5 \mathrm{ml}$ を加え 液量を $45 \mathrm{ml}$ にし，10\%モリブデン酸 アンモニウム溶液 $2 \mathrm{ml}$

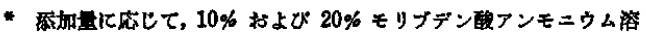

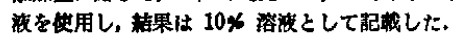

を加え，すみやかに湯竞上で各温度に 5 分間加温し，続 いて音温にまで冷却し $50 \mathrm{~m} l$ に希釈して四光保数を測定 した。加温温度と四光保数の関係を示すと第4 四(A)の とおりである。同四(B)に示したように，常温付近でも モリブデン酸アンモニウム溶液を加え，ただちに希釈し た後，20〜30 分間放雷すると発色率は 100\% 亿達する。 しかしなるべく迅速にケイモリブデン酸の生成を完成す るために, $50^{\circ} \mathrm{C}$ に分間加温した後, 室温冷却し一 定容積に希釈して吸光保数を測定するととにした。
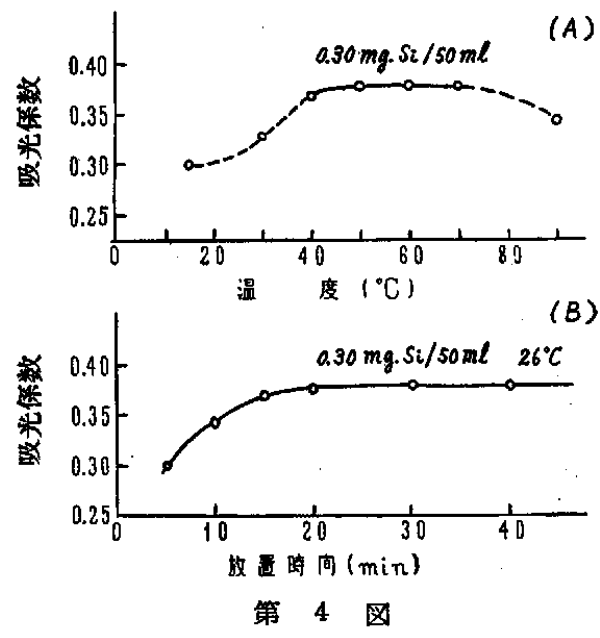

(5) 共存元䅈の影第

鉄鎇中のケイ素を N に述べる方法で定量する場合， 此色溶液中に残る主な元素は, リン, 七素, チタン, ハ ナジウムおよびアルミニウムである。リン，七素は弱酸 性下でケイ素と同様に黄色モりブデン酸錯塥を生じ比色

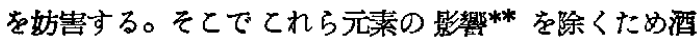
石酸, クエン酸, シュウ酸をアンモニウム壏の形で用い, その好果を比較した。その結果は第 5 四に示したとおり であってケィモリブデン酸溶液の吸光係数は，酒石酸 (0.044 mole) の添加 5 分後には, 0.380 から 0.310 に 減少する。しかしその後吸光俰数の翌化ははとんど翟め られず 120 分後でも 0.303 である。一方クエン酸, シュ ウ酸を添加した場合には，吸光係数は最初急激に淢少し， その後も徐々に減少を続け 120 分後でも一定の值に達し ない。リンモリブデン酸はどの有機酸を添加しても第 5 罒に併記したように，ただちに約 95\% 上上退色する。 七素モリブデン酸はどの有機酸を添加しても完全に，か つ迅速に退色してケイ菜の比色に影警をおよばさない。 上上の実験結果からリンおよびヒ素の妨害を除くには，

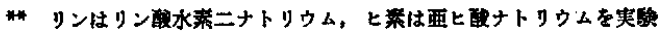
に拱した。 


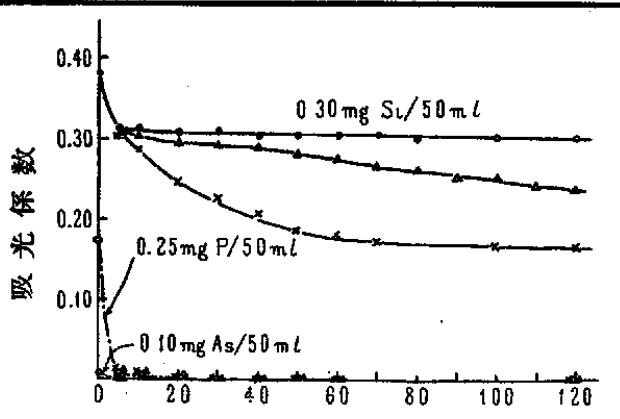

時 間 $(\mathrm{min})$

O: 0.044 mole 酩石转アンモニウム

$\triangle: 0.039$ mole クエン酸アンモニウム

X : 0.040 mole シュヴ祊アンモニウム

第 5 図

-3 種の有機酸中酒石酸が最も適当であるととが分る。

第6困は酒石酸アンモニウムの最適漊度をきめるため ケイ素 $0.35 \mathrm{mg}$ ，リン $0.25 \mathrm{mg}$ ，七素 $0.10 \mathrm{mg}$ を別個 に含む溶液を用い，前記 (4) のようにしてモリブデン 酸錯㙁を生成させ，種々量の酒石酸アンモニウム溶液を 加え，液量を $50 \mathrm{ml}$ にし， 20 分後に同量の酒石酸塩を 含むブランクに対して吸光保数を測定した結果である。 ての結果で明らかなように 10\% 酒石酸アンモニウム溶 液 $4 \mathrm{ml}$ を加えることによって，リンおよびヒ素の影翏 を除くことができる。との際ケイモリブデン酸溶液の曼 光係数は，武料溶液中のケイ素量が約 $1.5 \mathrm{mg} / 50 \mathrm{ml}$ 以 下の範用では, ケイ素量に無関保に約 $20 \%$ 減少する。

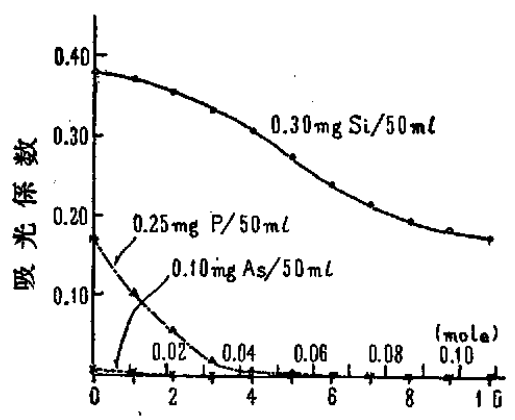

$10 \%$ 酒石酸アンモニウム溶液 $(\mathrm{m} l)$

第 6 図

また後述の（N) 法で，此色溶液中に残る元素のうち チタン,バナジウム，およびアルミニウム゙沙なくとも $1 \mathrm{mg} / 50 \mathrm{~m} /$ 以下であればケイ素の比色に影敕をおよはさ ない。マンガンも一部比色溶液中に残るが，少なくとも

" チタンは硫酸キタン, バナシウムはバナシン酸アンモニウム，ア ルミニウムは硫酸アルミニウム、、ンガンは硫酸マンガンを使用 した.
$2 \mathrm{mg} / 50 \mathrm{ml}$ 以下であれば比色に 影響をおよばさないて とを認めた。

(6) 検具線

樌淮ケイ素溶液 種々量 $(0.1 \sim 1 \mathrm{mg})$ を $150 \mathrm{~m} l$ フラ スコにとり，ほぼ和して $3 \mathrm{~N}$ 碳酸 $1.5 \mathrm{~m} l$ を加元液 量を約 $40 \mathrm{ml}$ にし，10\% モリブデン酸アンモニウム溶 液 $2 \mathrm{~m} l$ を加える。 $50^{\circ} \mathrm{C}$ 亿 5 分間加温した後，椧却し $10 \%$ 酒石酸アンモニウム溶液 $4 \mathrm{~m} l$ を加光全容積を 50 $\mathrm{m} l$ 亿希䣋する。溶液の一部を巾 $10 \mathrm{~mm}$ の液槽にとり 波長 $410 \mathrm{~m} \mu$ の単色光に対する吸光係数を測定する。ケ

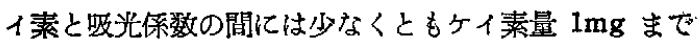
は Beer 則が成立する。とのようにして作成した㭘量線

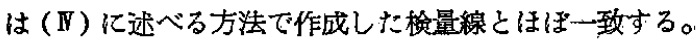

(7) ケイモリブデン酸溶液の安定度

ケイモリブデン酸の黄色溶液はきわめて安定で，酒石 酸猵を加えない場合には，少なくとも5 時間以内には吸

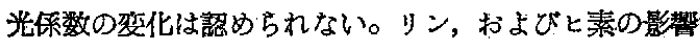
老除くため $10 \%$ 酒石酸アンモニウム溶液 $4 \mathrm{ml}$. を源加

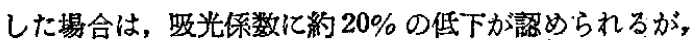
少なくとも2時間上内には吸光係数の新化はほとんど認 められない。しかしケイモリブデン酸が有機酸によって 徐々に還元され，約 2 時間後には青色制を带びてくる。

\section{IV. 鉄鋼中ヶイ素の比色定吾法}

鉄鎙中のケイ素をケイモリブデン酸法で比色定量する 掦合，多量に存在する鉄イオンか酸性溶液中で黄色を是 すること，ならびに試薬と複雑な反店をひき起すとと等 のため比色は不可能となる。そてで鉄イオンの影響を除 くに性（a）別に鉄量を定量し，ケイ素の比色值加らそ れ江基づく補正值を 差引くか（b) 適当な手段によっ てあらかしめ鉄イオンを除去するか, あるいは（c）適 当な試薬を加えて鉄イオンを鐠化掩羺しなければならな い。鉄イオン量がケイ素量の数倍またはをそれ以下である 埸合には（a）の鉄イオンによる補正を行えば，十分目 的を達することがでるるが，鉄鋼武料の場合にはての補 正は不可能である。てのような場合はフッ素イオンによ

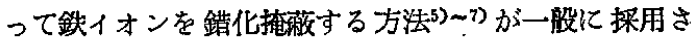
れているが，ガラス容器とくに比色計の石英製液槽が常 用中に次第に侵蝕されるので, 分析化学上好ましい方泆 とは言先ない。またクロム等が共存する場合には着色イ オンを生じその量に応じてかなりの誤差を伴なうから， それに基づく補正を行わねばならない。

ととろが，イオン交換榼脂あるいは水銀陰極電解法を 用いると，あらかじめ鉄，クロム、ニッケル，コバルト 
等の金属元素を除去するととができるので, とれらの元 素の存在を全く考虏するてとなくケイ素の比色定量がで きる。イオン交換樹脂法についてはすでに報告B)18)した ので本報では水銀䧔極帠解法を併用する方法について述 べる。

なお徉来の方法では酸に不溶性のケイ素化合物につい てはなんらの考慮もはらわれていない。ケイ素量の少 ない試料では往々その大部分か㳅溶性のケイ酸またはケ イ酸塩として存在しており，残查姏理を行わない場合に はかなりの誤差となる。そこで著者は分析操作中に残查 処理を付け加光た。

分析操作: 武料 $500 \mathrm{mg}$ 苍採取し, $3 \mathrm{~N}$ 硫酸 $20 \mathrm{ml}$ お よび過酸化水素水 $(15 \%)$ 約 $10 \mathrm{ml}$ を加えて 静かに 加

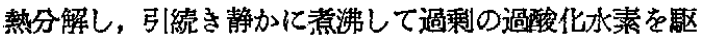
除し，少量の二酸化マンガンが生しるまで $1 \%$ 過マンガ ン酸カリウム溶液を滴加する。つぎに $3 \%$ 過酸化水菜水 を滴加して沈殿を分解し，さらに約 1 分間薏沸して過剩 の過酸化水素を駆除し冷却隻，白金管 $(20 \mathrm{ml}$ 容）を用 いて遠心分離し傾瀉して残查を溶液より分離する。残查 を数回 $1 \%$ 䂭酸で洗浄し遠心分離して乾燥させ，無水炭 酸ナトリウム $0.5 \mathrm{~g}$ を加えて溶融する。冷却後融塊を蒸 留水にとかし，さきの主液および洗浄液に合わせて，的 $\mathrm{pH} 1$ の溶液 $80 \mathrm{ml}$ にする。この溶液を水銀除極電解 槽に移し絶えずかきまぜながら 5〜8A で鉄イオンの反 応か謵められなくなるまで䁬解する。電解の進行と共に 溶液中の水素イオン婊度が喵大するから，適宜にビェレ ットからアンモニア水を滴加して電解中 $\mathrm{pH}$ を約 1 亿 調節する。㬐解終了後, 溶液を取り出し, 電解槽を洗浄 し三液わよび洗浄液を合する。これに 10\%モリブデン 酸アンモニウム溶液 $4 \mathrm{~m} l$ を加え， $50^{\circ} \mathrm{C}$ 亿 5 分閒加温 して発色させ，つぎに 10\% 酒石酸アンモニウム溶液 8 $\mathrm{m} l$ を加光て全容積を $100 \mathrm{~m} l$ 亿希釈する。この溶液の 吸光係数を波長 $410 \mathrm{~m} \mu$ の下で測定し，別に標準鋼を 使って上記操作に準して作成した积量線よりケイ素量を 求める。本法によれば $0.001 〜 1.0 \%$ の範囲のケイ素を 定量するととができる。

\section{v. 分 析 例}

（N）の分析操作にしたがって 鉄鎇中のケイ素を定量 した結果を第 2 表に示した。従来の方法, すなわち残查 处理を行わない錯化法で得た値は，同じく残查処理を行 わずに本法がびイオン交換樹脂法で求めた值 (A) と

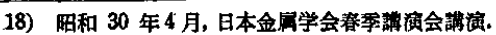

よく一致している。また残査边理をはどてした埸合の值 （B）も本法とイオン交換樹脂洪共によく一致している。 ところか残查中のヶイ素を考感に入れた值（B）は，そ

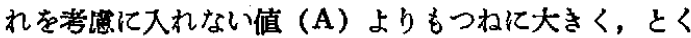

第 2 表

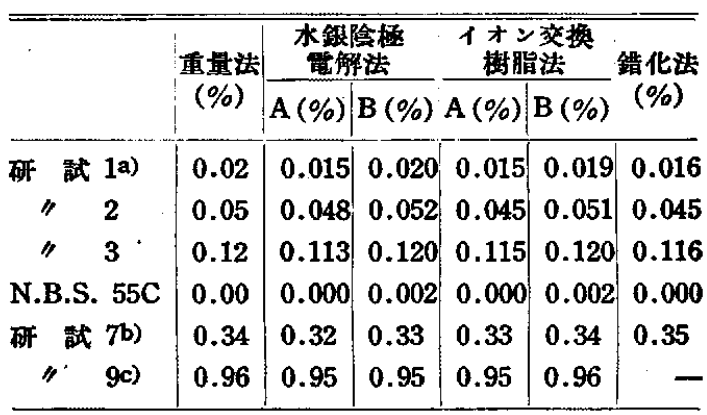

借䜤 a) 破試 $1 \sim 3 . \mathrm{C}: 0.1 \%, \mathrm{Mn}: 0.002 \%$, $\mathrm{Cr}: 0.003, \mathrm{O}: \sim 0.005 \%$.

b) ニッケル・クロム舒. $\mathrm{Ni}: 2.9 \%, \mathrm{Cr}$ : $0.80 \%$.

c）高速度銅. W: $20.1 \%, \mathrm{~V}: 0.62 \%$.

に微量ケイ素の定量には，この差を與視するととはでき ない。したがって比輷的にケイ菜量の多い武料（>0.05 \%)，あるいはさはど精度を閒題としない場合の他は,灰 酸ナトリウム溶僌萤行って不溶性残査中のケイ素化合物 をも合わせ定量せねばならない。残查中のケイ素は主に 無水ケイ酸または安定なケイ酸塩の形で存在している。

\section{VI. 絬吾}

鉄䤡中のケイ素をケイモリブデン酸法で比色定量する 場合, 彷来の方法は分析所要時間の短か心利点はあるが， フッ酸またはフッ化物を使用して多量の鉄イオンを錯化 掩跤するため, ガラス签器とくに比色用液槽が常用中に 侵蝕されるとと，クロム等が存在する場合には着色イオ ンができ，その量に応じてかなりの䜋差を生じるとと， および酸に不溶性のケイ素化合物が全く考盧されていな いとと等の众陷がある。ところが水銀陰橝䉓解法（また はイオン交換樹脂法）による陽性元素の分離と残査处理 を分析操作に付け加えて上記久陷をなくし，其好な結果 の得られるととを認めた。

終りに本研究に当って種々御助言を賜わった大啲大学 教滦相田竟太郎博士 氏，富永武彥氏に原く感㛛の意を表する次第である。な 抬本赫告にあたり多大の御援助を賜わった当破究部長高 尾善一郎氏に深謝子る㰠第である。 